APSA Annual Meeting -- August 28-31, 1997

\section{PROGRAM CALL FOR PAPERS}

Proposal Deadline: November 15, 1996

\section{New Institutions for a New Century}

Program Chairs: James Att, Department of Government, Littauer M-27, Harvard University, Cambridge, MA 02138 ; 617-495-2184; 617-496-5149 (fax); jalt@latte.harvard.edu; or Margaret Levi, Department of Political Science, Box 353530, University of Washington, Seattle, WA 98195; (206)543-7947; (206) 685-2I 46 (fax); mlevi@u.washington.edu

Division 1. New Institutions for a New Century James Alt and Margaret Levi

We share a commitment to explaining the origins and maintenance of institutions, of understanding when institutions facilitate and when they constrain equitable and efficient outcomes, and of determining how best to design institutions that promote political and economic development. The near approach of the 2ist century encourages us to look back at the institutional progress and failures of the past and compels us to consider institutional arrangements that will enhance the possibilities for the future.

In exploring the theme of "new institutions for a new century", we are particularly interested in emphasizing three sets of issues

1) Institutions as virtuous constraints. Much of the emphasis of institutional analysis is on constraints, and the bias in the discussion has been towards the negative effects of such constraints. However, as Montesquieu, Madison, and other great constitutional theorists have taught us, even constraints can sometimes enable. We are interested in exploring, empirically and logically, positively and normatively, this perspective that institutions prevent some actions while creating new opportunities.

2) Institutions and learning. Those who rely on economic approaches to politics are increasingly considering the effects of imperfect information. Those who rely on psychological approaches theorize about the effects of cognitive limitations. To what extent do institutions provide information, overcome cognitive limitations, and provide feedback that enables us to learn from our experiences? The relationship between institutions and social learning is a complex one, and not always socially advantageous.
When campaigners learn the advantages of negative ads or citizens the advantages of free-riding, the polity may be the loser

3) Institutions and conflict. Ethnic and racial animosity, domestic terrorism, civil wars, and other evidence of social polarization seem to be increasing, not diminishing, as the century ends. Can institutions lower the temperature of hot conflicts? If yes, what kinds of institutional arrangements will be most effective? Renewed interest in federalism, communitarianism, and small government reflect the search for institutional solutions, but what are the advantages and disadvantages of each of these proposals?

We hope to promote discussion of the origins of institutions as well as their consequences. An emphasis on institutions allows us to explore some of the great questions of political theory as well as some of the curtingedge approaches of modern social science. It permits us to think historically, comparatively, and constitutionally. It gives scope to all the varieties of contemporary political science, but requires a conversation among them if we are to in fact uncover some answers to the questions we have raised. We invite proposals for panels and papers, and will offer roundtables and plenary sessions, on as many of these questions as possible.

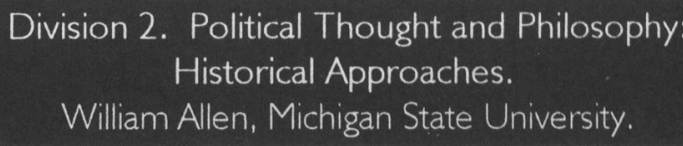

Taking seriously the organizing theme for the 1997 Program and working deliberately to address that theme within the context of the three sets of issues that have been emphasized, insofar as the development of political philosophy or the history of political development informs our understanding, we invite proposals for panels that will enable a general exchange on the relative weight to be accorded these conceptual foundations.

Because other divisions will explore specific methodological approaches toward the explanation or development of new institutions, it is appropriate for proposals in this division to focus on the fundamental questions deriving from conceded historical or philosophical occurrences. For example, constitutionalism anciently won acclaim as a good; democracy anciently won scorn as an ill. At the advent of the modern era, the two terms converged such that democracy became the only substantive content for the process called constitutionalism. This altered perspective did not merely evolve but was rather ushered forth as a consequence of serious argument and long reflection on the part of thinkers and political actors who eventually abandoned the ancient distinctions and came to view 
democracy as a necessity at minimum and potentially a good in and of itself.

Understanding the arguments of a few of the architects of liberalism assumes background familiarity with the ideas of classical political philosophy right up through Machiavelli. Simultaneously and correlatively with the attered moral and political perspectives the process engendered diverging conceptions of the nature of political and social study -political science. We may yet question whether we fully understand how political and social study came to be defined, as well as how constitutionalism and democracy came effectively to be synonyms. In that context, the demands to be made of new institutions are correlates of the demands to be made of historical and philosophical understanding. Do institutional constraints enable as well as restrain? Do institutions structure learning and understanding sufficiently to justify expectations keyed to original intentions? Does the transition from ancient constitutionalism to contemporary democracy justify a treatment of the tendencies of institutions as central to a determination of human prospects?

When we investigate the idea of founding, we are animated by a principal question, namely, who or what is a founder? What does it mean to found a regime? Are founders in any way different from ordinary legislators? We may of course respond to this inquiry by means of an in depth review of important prior writings on the subject, beginning in the ancient world and proceeding by way of commentaries in the intervening periods since. The point, however, is to awaken a concern about the question of founding in our time, particularly as that is illuminated by the kinds of political processes now underway in numerous countries. It is reasonable, moreover, to inquire whether the emergence of a new concern with institutions, or a new constitutionalism, necessarily points to our having surmounted the radical moral, political, and intellectual challenges to liberal democracy.

The point of the foregoing discussion is to suggest the range and focus of topics that may happily respond to the "commitment to explaining the origins and maintenance of institutions, of understanding when institutions facilitate and when they constrain equitable and efficient outcomes, and of determining how best to design institutions that promote political and economic development." I wish to encourage proposals for sharply focused panels and/or roundtables that make the philosophical or historical understanding of political well-being the central inquiry.

Division 3. Normative Political Theory.

Wendy Brown, University of California, Santa Cruz.
With the possible exception of liberal political thought, political theory has borne an ambivalent relationship to political institutions, tending to be more attracted to other elements of political life--ideas, action, principles, even events. Does this ambivalence, which sometimes emerges as forthright hostility and at other times as erasure, derive from the very enterprise of political theory, from a certain rivaly with institutions for pride of place in politics? Might institutions constitute the site at which political theory experiences its impotence in relation to political life? Do institutions especially appear to constrain normative political theory's supra-historical or transcendent reach? Or, insofar as institutions are crucial vehicles and repositories of power, is the eschewal of institutions by political theory part of a larger tendency toward the avoidance of power as the central currency of politics? Do institutions represent the loss of punchase of ideas in politics, the loss of the 'doer behind the deed', the element of politics that Weber drearily characterized as 'the strong and slow boring of hard boards'? Finally, if it is the case that liberal political thought has dealt more directly with institutions than any other genre, why?

These questions are intended to provoke certain possibilities for panels and papers circumscribed by this year's theme but not to exhaust those possibilities. Proposals for papers concerning all elements of normative political theory, broadly construed, will be welcome.

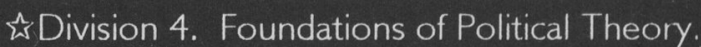
Jane Bennett, Goucher College.

The Foundations of Political Theory Section encourages a wide array of voices, approaches, and interests in political thought. I welcome proposals that address the 1997 APSA theme "New Institutions for a New Century" either by applying it to debates within political theory or by challenging its priority by working within an alternative frame of reference.

Pursuing the idea of institutions as "virtuous constraints," I particularly encourage explorations of the ways in which aesthetics and ethics also function as constraints that enable. Kant, for example, developed complex connections between aesthetics, morality, and public life. Burke, Nietzsche, Thoreau, Adorno, Arendt, and Foucault have forged a variety of other links, while many contemporary neo-Kantians caution against the "aestheticization" of ethics and politics. What dangers and possibilities reside at the intersections of aesthetics, ethics, and politics? How do artistic disciplines, religious exercises, practices of health and beauty, norms of theoretical clarity, rules of civility, or 
experiences of the sublime inform politics? What aesthetic visions shape campaign advertisements, military organization, entertainment media, the experience of the nation, gender identities, postcolonial projects, or environmentalist strategies?

Given this emphasis, I am also interested in proposals that give thought to how material will be presented, discussed, displayed, or enacted. In other words, I encourage reflective experimentation in the form of presentation.

\section{Division 5. Formal Political Theory}

Jeffrey S. Banks, University of Rochester

Proposals are invited for papers, or panels (consisting of three papers along with discussants) on formal models of political institutions and of political phenomena more generally. The theoretical techniques pursued in the proposals may take on a variety of shapes and sizes, and need not be restricted to game-theoretical analyses. Similarly, the substantive area of inquiry may range far beyond the traditional topics of elections, behavior in legislatures, coalition formation, and the like. In keeping with the theme of the 1997 meetings, proposals that address questions concerning institutional persistence (e.g. institutions as equilibria), institutional influences (e.g. institutions as constraints), and other aspects of and perspectives on political institutions are especially encouraged. In particular, comparative analyses of institutional arrangements, on topics such as fiscal and political federalism, constitutional and legislative rules, the structure of international alliances, and so on, which employ a formal modeling approach would be prime candidates for inclusion in the program.

In addition to theoretical papers, papers which test the empirical predictions arising from existing formal models are also encouraged. Techniques here may include (but are not limited to) traditional statistical analysis, experimental methods, and computer simulations.

Paper proposals should include an abstract; panel proposals should include paper titles and abstracts, and a list of participants.

\section{出 Division 6. Political Methodology}

John Brehm, Duke University.

The political methodology division welcomes proposals for papers or panels for the 1997 meetings. Political methodology has a special capacity to contribute to the theme of the 1997 conference, the study of institutions, in the development and application of tools for research across subfields and research paradigms. I particularly encourage proposals for papers or panels which provide for methods for comparison across institutional settings, which help to adjudicate competing claims about the motivations of different actors within institutional settings, or which contribute to the resolution of debates across institutions.

Recent papers in the political methodology division provide prototypes for the kinds of proposals that could well fit the theme of the conference. Problems arising from the nature of the data collection are endemic: I welcome papers developing or applying methods for handling missing data, for drawing inferences across levels of data collection, or for creative means to gather data in experiments, simulations or other research designs. I encourage the submission of proposals for papers which critique commonly deployed methods.

I especially encourage proposals for papers which develop new technologies, such as those which attend to limited dependent variables in time-serial problems, those which apply methods from statistics or econometrics which have received less attention by political methodologists (e.g. those which discuss Bayesian methods, or the properties of mixtures of distributions), or papers which model the systematic components of parameters of distributions on which little research has focused up to now (e.g., covariances, dispersion).

\section{« Division 7. Legislative Studies. \\ Sue Thomas, Georgetown University.}

The elections of 1992 and 1994 brought, respectively, the first instance of unified federal government in the United States in 12 years, followed by another period of divided government, this time with Republicans in control of Congress for the first time in 40 years. These circumstances provide wonderful opportunities to explore topics related to the theme of the convention, "New Institutions for a New Century." The 1996 races, whatever their outcomes, are likely to extend these opportunities.

As such, submissions related to institutional change and accommodation relating to structure, rules, partisanship, ideology, and divided or unified government are especially welcome. Papers and panels concerning policy development and outcomes in altered circumstances are also of great interest. I further strongly encourage submissions exploring the ways in which issues related to race, gender, and class have been affected by changing legislative and political environments.

The Republican electoral success of 1994 was evident at the state as well as the federal level. Hence, papers and 
panels related to institutional change and accommodation in the states are encouraged. Similarly, comparative legislative papers on these topics are most welcome.

Finally, I look forward to receiving proposals on the full range of topics related to legislatures that engage scholarly imaginations. I urge all those who submit proposals to use the form offered in PS so that all relevant information is included.

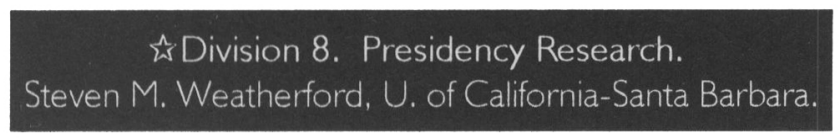

Presidency researchers will welcome the conference theme, "New Institutions for a New Century." The emphasis on institutions will foster attention to patterns and systematic comparison, and thus offer an opportunity to rebut the canard that presidency studies are anecdotal and atheoretical, while the pointer toward the future will encourage constructive speculation, an activity presidency scholars relish.

If we conceive of institutions broadly, as patterns of activity and expectations -- whether explicit and acknowledged or not -- that help cope with some decisional or collective action problem, then it would seem that the encouragement to think about our topic with an eye to institutions would turn up a host of thought-provoking questions. For instance, how and how much are relations between the presidency and various audiences institutionalized, and how does this shape or constrain the president's interactions with the public, the media, and organized interests? How have the various intelligence and advisory functions serving the White House been institutionalized, and has the presence or absence of stable patterns influenced the quality of advice or the efficiency and bias of policies? And how have patterns of interactions between the president and the bureaucracy, and the president and Congress -- both coalitional and conflictual -evolved as the individuation of legislative power has grown and divided government become a way of life?

These suggestions are meant to stimulate not circumscribe proposals that pursue the theme of the conference, and promising ideas on other manifestations of institutions are invited as well. Finally, although proposals pursuing the conference theme are encouraged, I emphasize that proposals for papers, panels, or roundtables are enthusiastically welcomed on any aspect of presidency research. I encourage proposals for complete panels, roundtables or innovative formats, especially those that undertake systematic comparison, for instance across presidents, historical eras, or methodological approaches.
Please include a title and abstract detailing the proposed paper. For panel proposals, an abstract of each paper (for roundtable proposals an outline of the subject matter and approaches envisioned), along with names, affiliations, and addresses for all the participants. If you are interested in participating as a discussant or panel chair, please include a brief statement outlining your research interests.

\section{\& Division 9. Public Opinion and Participation}

Rudolfo de la Garza, University of Texas, Austin

In keeping with the theme of the convention, this section invites proposals for papers and panels that focus on the traditionally salient themes in public opinion and participation as well as proposals that address new issues that in the next century should be especially relevant to the study of public opinion and participation. For example, what is the impact of talk radio and the internet on public opinion? On communication between citizens and elected officials? On voter mobilization? On how citizens and noncitizens learn about and engage the polity? How do changes goveming voter registration and voting such as the motor voter law, generous absentee and early voting provisions and elections-by-mail affect electoral participation?

The changing ethnic and racial composition of the nation combined with an increased proportion of foreign born residents and citizens also bring into question the continued utility of the models that have been traditionally used to explain public opinion and participation. Do the factors that shape public opinion among US-born English speakers also explain public opinion among immigrants? Where do immigrants, especially the non-English speakers, get their information about the polity? What information do they get? How does this affect their participation? Do these immigrants come with distinctive participatory norms? Does the presence of these new groups affect the style and level of participation among native-born citizens? Does it affect the policy preferences of the native born?

Proposals for topics other than these that address public opinion and participation are also invited. The scope of the papers/panels may vary from local to national to comparative. Indeed, papers/panels that deal with the demographic issues described above from a comparative perspective would be especially welcome.

$\stackrel{\star}{\star}$ Division 10. Elections and Voting Behavior. Laura Stoker and Henry Brady University of California, Berkeley. 
The study of political behavior has sometimes been contrasted with institutional research, but in the last decade there has been an increasing realization that electoral behavior must be understood within the context of institutions. The institutional environment includes federal versus unitary systems, presidential versus parliamentary government, electoral rules, political parties and interest groups, the mass media, legislative apportionment, nomination methods such as primaries, caucuses, and conventions, the traditions of political campaigns, and the legal restrictions on how campaigns are financed and run.

Atthough we welcome voting research that explores the role of socio-economic characteristics, party identification, and other political attitudes and beliefs, we especially invite papers that link voting and electoral outcomes to institutional factors. For example, are voters more or less likely to consider leader characteristics, issues, or party in presidential or parliamentary elections? Do voters split their votes between levels in federal systems or between the legislature and the executive in presidential systems? Do voters act strategically when there are more than two candidates in plurality or single non-transferable vote electoral systems? How does candidate choice differ across conventions, caucuses and primaries? Do voters get more information and make more informed choices in deliberative polls? What institutional mechanisms such as free media, debates, or paid advertising provide the most useful information to voters? How does polling affect candidates, campaigns, and voters? In what sense are political campaigns institutions with established norms and practices? What are the institutional barriers and limits to third parties in the United States? How have changing institutional practices such as absentee balloting, motorvoter, and mail ballots affected turnout and voting? How well do the mechanisms of direct democracy such as the initiative, referendum, and the recall work? What impact do institutional changes such as term limits have on candidates, campaigns and voters?

\section{«Division 11. Political Organizations and Parties.} Burdett Loomis, University of Kansas

Comparative studies including those of emerging democracies around the world will be especially welcome. But any and all interesting proposals on elections and electoral behavior will be gratefully received and carefully considered.

As much as any other set of institutions, political parties and the wide range of organized interests serve to constrain (and enable), to instruct (for better or worse), and to reduce conflict (or exacerbate it). These institutions are both old and continually renewing themselves, whether for a "new century" or for the next round of political contests and policy battles.

This division encourages the submission of proposals for Individual papers, entire panels, roundtables, or some combination, such as several discussants for a single, major paper. Timely submissions will be regarded favorably. The program committee's broad themes of how institutions channel "virtuous constraint," learning, and conflict should suggest a host of important and interesting topics. Most significantly, perhaps, the growing popular distrust of government has focused attention on the capacity of mediating institutions to build effective majorities and represent the panoply of societal interests. Indeed, the issue of representation lies at the heart of the political organizations and parties subfield.

The notions of constraint, learning, conflict suggest that we might pay systematic attention to the many forms of lobbying, especially as the stakes of political decisions increase (e.g. health care, telecommunications). Proposals from various theoretical and methodological schools are strongly encouraged, as are those that explore political organizations and parties from a comparative perspective. Likewise, comparative research from the American states will be welcomed. As entities that continually reinvent themselves, political organizations and parties will surely reconstruct themselves into "new institutions for a new century." But the questions of: "How? How new? With what impact?" remain to be addressed, to say nothing of being answered.

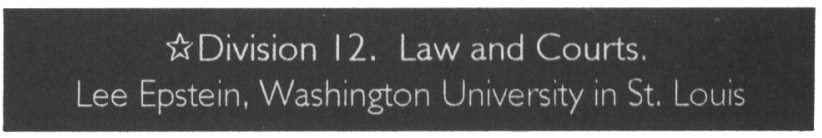

After years - even decades - of "more of the same" research, the field of Law and Courts is experiencing something of a renaissance. We judicial specialists are now asking a range of interesting and new substantive questions, we are invoking theories that differ markedly from those we employed in the past, and we are developing creative ways to assess predictions generated by the models. Perhaps even more important is that, for the first time in recent memory, those who labor in other fields are beginning to see the value of our work. Congressional scholars interested in the operation of the American separation of powers system no longer treat courts as exogenous actors and comparativists concerned with democratization have also come to realize that their accounts may be incomplete without attention to judicial fora - to name just two. 
My primary objective for the 1997 meeting is to assemble panels that reflect this extraordinary rebirth of our field. 1 am, thus, particularly interested in research - both by judicial specialists and scholars who locate themselves in other fields of political science - that tackles questions on the goals of judicial actors; on strategic behavior on the part of jurists and lawyers, and the implications of such behavior for the ultimate state of the "law;" on the role of rules, norms, and conventions in structuring the interactions among judges sitting on collegial courts, between members of lower courts and higher ones, and between jurists in all arenas and legislators and executives; on the operation of courts in the larger political regime - here or elsewhere; and on the relationship between the mass public and legal tribunals.

Of course, I remain open to papers that take on the perennial concerns of our field and to those in areas I have not identified. The only proposals I discourage are those seeking to create entire panels or roundtables; experience suggests that such requests are difficult to accommodate.

\section{Division 13. Constitutional Law and Jurisprudence.}

Michael Combs, University of Nebraska, Lincoln

Papers and panel proposals in all areas of constitutional law and jurisprudence are encouraged. Requests to serve as discussants or chairs are also invited. I especially solicit submissions that focus on the conference theme "New Institutions for a New Century."

First, with this theme in view, I hope to have at least one panel and roundtable that examine how constitutional interpretations bring about the evolution and transformation of institutions. The question becomes: Do we then have the creation of new institutions or "new wine in old bottles"? Second, I encourage proposals that concentrate on how constitutional interpretations create, expand, and even constrain the rules-of-the-game that govern institutions, and on the consequences of changes of the rules-of-the-game. Third, I welcome papers relating to how the life and jurisprudence of individual jurists influence the development of constitutional law. Fourth, I solicit papers and panels that address how jurisprudence relating to race, ethnicity, and gender impact the formation and operation of institutions. Fifth, 1 also encourage papers that employ various analytical, historical, doctrinal, and value approaches in the examinations of the work of courts, including the Supreme Court, lower federal courts, and state courts.

And finally, I welcome proposals that are interdisciplinary and methodologically or theoretically innovative. $I$ also welcome proposals that concentrate on comparative constitutional law and politics.

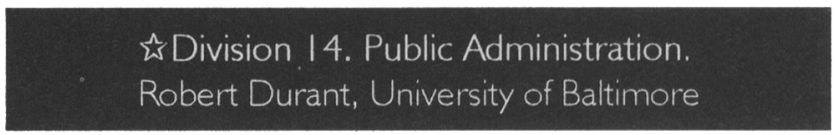

With the 60th anniversary of the Brownlow Committee's Report on Administrative Management (1937) approaching, with the 50th anniversary of Dwight Waldo's The Administrative State (1948) following shortly on its heals, and with the 25th anniversary of Vincent Ostrom's The Intellectual Crisis in Public Administration (1973) looming on the horizon, no more timely APSA conference theme exists for public administrationists than "New Institutions for a New Century."

The APSA conference committee is especially interested in our thinking empirically, logically, and normatively about how present or prospective institutions either foster or impede our ability to innovate, to learn from our experiences, and to reduce or more positively channel conflict among actors. I invite paper and panel proposals that address these and other public administration developments, topics, and consequences from the perspectives of either subfields or the field as a whole. Certainly, contemporary public administration in both the United States and abroad functions in an evolving institutional setting (structural, processual, cultural, attitudinal, and normative) that differs markedly from that either described or prescribed by the Brownlow Committee, Waldo, or Ostrom. Indeed, today's public administration context has at least six primary, challenging, and unparalleled institutional features that should stimulate panel and paper proposals.

First, rather than seeing government as the solution to market failures, critics of the administrative state see markets and quasi-market competition as the solution to government failures. Second, whereas centralization, regulation, and bureaucratization drove the administrative reform agenda from the New Deal through the 1970s, "devolution, deregulation, and debureaucratization" drive the agenda of contemporary administrative reformers. Third, governments at all levels are viewed increasingly as catalysts for action by third-party actors, rather than as direct service providers. Fourth, public managers must operate in non-hierarchical alliance-based networks (or implementation structures) within nations coping with fiscal stress, with high levels of citizen distrust of government, yet with soaring demands for government services. Fifth, working the "seams of government" in this fashion and environment with a culturally diverse workforce requires new interpersonal and human resource management skills, enhanced financial acumen and innovations, and strategic information management approaches. Finally, agencies are 
pressed more routinely to become outcomes-based (or results-oriented), to focus on long-range priority setting, and to become more sensitive to a diverse universe of stakeholders. These efforts, however, are sorely complicated by elected and judicial overseers whose predispositions are procedurally based, whose time horizons are short-term, and whose focus is particularistic rather than broad-based.

Empirically based and theoretically grounded paper proposals will be viewed most favorably, and proposals for roundtables and nontraditional formats (e.g., "author meets critics") will also be entertained. Proposals should include a one- to two-page abstract summarizing details of the topic, methodological and theoretical approaches employed, data sources, and relationship to the conference themes. If proposing a full panel, it is necessary to have prior agreement from proposed panel participants. All communications should provide the full name, rank, institutional affiliation, telephone number, fax number, and e-mail address of proposed participants.

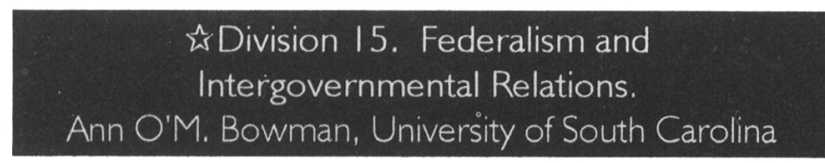

Interest in federalism and federated systems is high as the century draws to a close. Related to that, relationships between governments--be they center-periphery, interlocal, or regional in nature--are changing. Proposals are encouraged that, whatever their substantive focus, capture the dynamism of federalism and intergovernmental relations. Further, proposals applying inventive analytical methods are welcomed.

As to substantive focus, papers that explore issues of longstanding interest to students of federalism and intergovernmental relations are encouraged as are papers that tackle emerging concerns. Examples of the former include topics such as the role of the courts in adjudicating intergovernmental disputes, fiscal federalism, tensions between the national and state governments, and comparative federalism. Examples of the latter include topics such as Euro-federalism, intergovernmental competition and cooperation, regionalism, and the impact of devolution and decentralization on subnational governments. In addition, papers that adopt a public policy approach to intergovernmental issues are welcomed. Given the overall convention theme, papers that address the institutions of federalism in a particularly creative way are sought. As always, this list of possible topics is intended to be suggestive, not exhaustive.

Proposers are requested to use the APSA's "Individual
Paper Proposal" and "Organized Panel Proposal" forms that appear in PS. In addition, a one page abstract should be included specifying the topic, the theoretical base, the methodological approach, and the significance of the work. Alternatives to traditional panel formats, e.g., roundtables, "meet the author" sessions, scholar-practitioner events, and poster sessions are solicited.

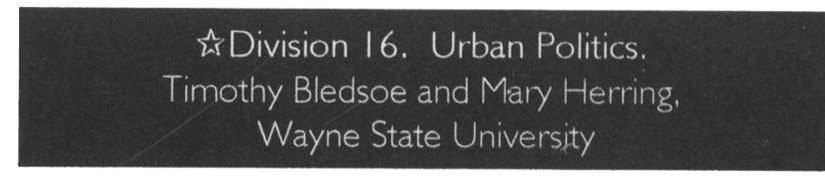

We invite proposals from across the spectrum of urban politics, but we are especially eager to receive submissions reflecting the convention theme. Theme-related topics might include the role of semi-public institutions (churches, business organizations, community-based groups) in shaping urban political processes and outcomes; the role of municipal institutions in ameliorating or exacerbating conflict along racial, ethnic, economic, or partisan lines; or the nexus between institutional traits and elements of political leadership. Ourforemost concern, however, is identifying proposals that represent the rich diversity and cutting-edge quality of contemporary urban politics research. Proposals for papers of the case-study or comparative case-study variety should explicitly state the conceptual or theoretical contributions of their research and how their findings will be of value to the broader community of urban scholars. Proposals for data-based papers should address these issues as well, but should also describe the data set upon which their study is based. Individuals interested in presenting a paper should submit a one-page abstract that provides a brief overview of the paper. Proposals for panels must provide an abstract for each paper. Proposals for roundtables must include a statement about the subject matter to be addressed as well as information about each participant. Requests to serve as discussants or panel chairs are also welcome and should be accompanied by a brief curriculum vita.

\section{^ú Division 17. State Politics and Policy Jan E. Leighley, Texas A \& M University}

One of the central agenda items of Congress over the past two years has been the devolution of policy initiative and implementation to the states, with recent changes in health care and social welfare policies being among the first to witness the translation from symbolism and rhetoric to real politics. This devolution is likely to be one of the defining characteristics of state politics in the "new century," thus raising a number of issues that demand rigorous scholarship. Our division will focus on two such issues. First, how will state institutions respond to these new responsibilities? will new institutional structures emerge? 
weak institutions become strengthened? Second, what particular features of state institutions and politics will structure the policy responses of the states? and will state institutions, acting as "virtuous constraints," produce more efficient, or more responsive, policy decisions?

I welcome paper proposals that address these questions, as well as significant, enduring issues in the study of state politics and policy. I will give priority to papers that are comparative in nature; balance out the division with panels on both politics and policy; and give preference to papers that are in progress as of the proposal deadline. I hope to have at least two panels with papers that explicitly address aspects of the meeting's theme, "New Institutions for a New Century."

I will, of course, consult closely with the divisions on Federalism and Public Policy, so as to maximize participation in the meeting. In doing so, I hope to broaden the division's offerings to topics beyond substantive policy areas and include papers on state elections and public opinion, as well as the "causes and consequences" of policy-making in the states.

\section{虫Division 18. Public Policy.}

Hank Jenkins-Smith, University of New Mexico

The primary theme of the APSA conference this year is "new institutions for a new century", with emphases on the roles that institutions play in constraining and encouraging actions, fostering learning, and managing conflict. Such a theme is particularly appropriate for public policy scholars, for whom these themes have been prominent in recent years. In that spirit, I welcome proposals for papers and panels that focus on the ways in which institutions play systematic roles in all aspects of the public policy process.

In addition to (and in combination with) the focus on institutions, proposals for papers on comparative public policy, policy processes and change, substantive policy areas, and other aspects of public policy will be welcome. Proposals for papers and panels that discuss the integration of the public policy theory with theories developed in other fields (e.g., public opinion, methodology, political theory) are encouraged. Overall, the panels and papers should reflect the best of the diversity and vitality of the public policy subfield.

Paper proposals should include an abstract that clearly identifies the research question(s), the methodology or approach employed, and the contributions that the paper will make to the policy subfield. Panel proposals should include the general topic, the names and affiliations of the proposed panel participants (with proposed paper titles for each), and a succinct justification for inclusion of the panel in the program.

\section{$\stackrel{\star}{*}$ Division 19. Political Economy. \\ William Bianco, Penn State University}

Reflecting the diversity of the subfield (or, perhaps, the various attempts to appropriate the label) political economy panels typically cover a wide range of topics. I expect that the 1997 crop will be no exception. While I would be happy to entertain proposals falling into the category of "usual suspects" (e.g., international trade, macroeconomic policy, collective action, or new institutionalism), I invite proposals, either in the form of papers or ideas for entire panels) falling into three areas. First and foremost are proposals which use results or techniques in political economy to address the theme of this annual meeting. Second, research that aims to unify work in political economy with more mainstream approaches to the same questions. Analyses of institution selection or the role of norms and culture are but two possibilities here. Third, and along the same lines, I would be extremely pleased to see proposals that bridge models or methodologies, both within the subfield (e.g., models of legislative policy-making with analyses of the domestic forces behind trade policy) and across subfields (e.g., rational choice and political psychology). Scholars are also encouraged to submit ideas for co-sponsored panels.

\section{« Division 20. Women and Politics Karen Beckwith, College of Wooster}

The theme "New Institutions for a New Century" offers women and politics scholars the opportunity to consider institutional arrangements from two important perspectives: first, by examining the relationships of institutions and women to each other, and second, by investigating and elaborating the ways in which institutions are gendered. The relationship of women to institutions can be conceived in terms of women as institutional actors or women "in" institutions; as the subjects of institutions, influenced and affected by institutional arrangements, policies, practices, and institutionally-created opportunities; and as external political actors who seek to transform state structures, policies, and practices.

By focusing simultaneously on "women" and "institutions," we can undertake to assess the impacts on women's status, activism, and opportunities for mobilization and for governance. At least four possibilities for thinking about "women and institutions" emerge. First, as institutions and institutional arrangements persist, how does this stability and continuity affect women? What are women's 
prospects in a new century in political systems that fail to adapt or that defend their stasis? Second, as institutions change and are reformed, how do these transformations involve women and with what results? Third, as political systems and states change dramatically, as new states emerge, as "old" states collapse, how are women involved in the necessary work of creating truly new institutions in a new state? How does the requirement of complete institutional (re)construction position women in these states? Finally, how will transnational and international institutions, practices, and behaviors involve and affect women? As institutional locations shift from the nationstate to international relations, we can investigate women's response to and engagement in these changes.

In addition to a "women and institutions" perspective, a focus on the gendered nature of institutions --their structures, their personnel, their cultures and practices -- is imperative for the understanding of women and politics in new institutions in the new century. What are the explicitly gendered arrangements of political institutions in various states? How are apparently nondiscriminatory institutional arrangements implicitly gendered, by whom, and to what effect? What institutional arrangements would be necessary to establish a "woman-friendly polity" and how could those institutions be created? In regard to "gendered institutions," comparative scholarship -- whether longitudinal across "old" and "new" centuries or crossnational -- may offer the greatest scope for answering these questions. Political behavior and attitudinal research, organizational and mass behavior perspectives, international relations scholarship, and other approaches to investigating issues of the gendered nature of institutions are also necessary. Feminist theory, in particular, has contributed important answers.

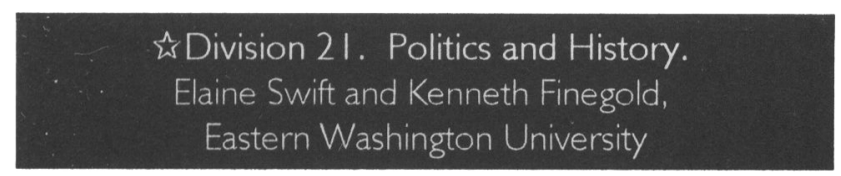

I welcome paper and panel proposals addressing these questions, as well as others not specific to the convention theme. I particularly welcome proposals for a themespecific panel on creating new institutions whose political arrangements will enhance women's life chances. I will give priority to proposals that are complete and meet the APSA submission format and deadline.

The theme of the 1997 Annual Meeting, "New Institutions for a New Society," provides a welcome opportunity to tie the historical study of institutions to the analysis of their contemporary characteristics and future development. Many of us in the Politics and History Section have long been interested in questions of institutional origins, institutional maintenance, and, perhaps most of all, institutional change. In keeping with the meeting theme, we invite paper and panel proposals that explore the causal relations that link institutions and exogenous forces, including other institutions; the learning that takes place within institutions and the institutional framing of political debate; and the ways institutions both shape and are shaped by conflicts over class, ethnicity, gender, ideology, race, religion, and sexuality.

To build theory for the historical study of institutions, we encourage proposals that import perspectives from other disciplines or address meta-theoretical questions such as the conception of time, the use of narrative, or the definition of institution. We are also interested in papers and panels that cut across the traditional field divisions of American politics, comparative politics, international relations, and political theory. In addition, we look forward to receiving proposals that experiment with innovative panel formats that stimulate interaction among panelists and invite audience participation.

Politics and History Section panels traditionally feature a rich mix of scholarship. We therefore welcome proposals that reflect your research interests that may not be covered by the suggestions above.

When submitting your proposal, please use the form provided by the APSA. Please be sure to clearly indicate your e-mail address on the form. We strongly encourage dual submissions to other pertinent divisions.

\section{^ Division 22. Comparative Politics Nancy Bermeo, Princeton University}

The Comparative Politics section seeks original arguments about the origins and effects of political institutions. Works that deal with the interaction of institutions are of special interest. These might focus on one of four research areas:

1) Interactions between regions. What resources do different regional institutions bring to their interactions? What are the effects of globalization on the nature of interregional interaction? How and why do regions shift in importance and power? What shifts and continuities are we likely to see in the next century?

2) Interactions between the public and the private. How and why are private institutions successful in affecting public ones? How and when are public institutions dominant instead? How do private interests get organized and institutionalized in the first place? When does the nature of the public vs. private interaction foster equality or efficiency? When does it foster disaster? What does past experience 
teach us about the best locale for new institutional initiatives?

3) Interactions between cultural institutions and others. How do institutions that concem themselves primarily with the dissemination of ideas interact with those that were founded to serve another purpose? e.g. How do the nature of schools or universities or media affect the leaders and targets of government programs? When do states change their interactions with cultural institutions and what happens when they do? When do cultural institutions contribute to a change in state institutions? How does this affect multi-cultural societies?

4) Interactions between the established and the new. How do established institutions affect new ones and vice versa? When do established institutions generate new ones? When do they expand or disintegrate instead? What sorts of new institutions are likely to emerge and survive in the first decades of the new century?

Papers on other themes will be considered too. Those that raise new debates, that use primary sources or that use interdisciplinary approaches are especially welcome as are papers from scholars who live and work outside of the United States.

\section{Division 23. Comparative Politics of Developing Countries. \\ Robert Bates, Harvard University}

No less than other portions of the world, developing societies face new challenges in the 21 st century. Among these is the creation of institutions that facilitate development and growth.

The study of development is often mis-classified as a subfield of comparative politics. Development refers to variation over time, not variation over space. Its study focuses on political and economic states that are a function of time: growth and decay, expansion and disintegration, and development or under-development, for example. A theory of development therefore should take time explicitly into account. How would "putting time back in" affect its study? In particular, how would it affect our understanding of the significance of institutions for the development process?

How, for example, do institutions solve, or fail to resolve, problems of time consistency? How do they help or hinder the making of commitments? How do political institutions promote or retard the inter-temporal transformation of economic resources, as in the formation of capital? How do they reduce - or fail to reduce - political insecurity, and thus alter the weight of the shadow of the future on present-day decisions? How do they link, or fail to link, generations, promoting, or failing to promote, the welfare of future members of society? Panels devoted to the study of these and related themes would be especially welcome.

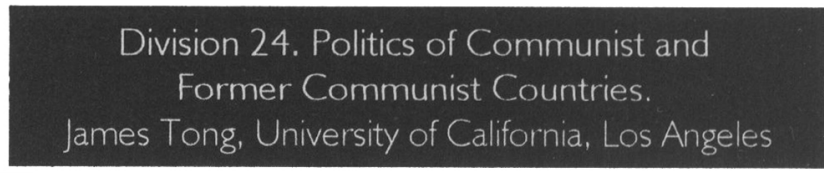

While not limited to the following, the section solicits panel proposals that address the conference theme on new institutions and related questions. I welcome papers that survey the plethora of emerging political and economic institutions in post and transitional Communist states, explain their evolutionary origins and states, analyze their continuity and change from antecedent institutions, and query why some complete the metamorphosis while others become still-born. As centralized Leninist states crumple, nomenklatura and democratic centralism lose their spell, what principles and mechanisms govern the political and economic relations between and among different levels and branches of governments, party and state, civilian and military bureaucracies? To what extent are emerging structures the result of constitutional design, social learning, evolutionary accident, or simply muddling through?

In this historic process of regime transformation, do the new party systems and legislatures mirror social cleavages, converge or diverge with market forces to generate or ameliorate social inequalities? To what extent does the new regime structure and political correctness constrain or enable the political elite to play the respective roles of delegates, trustees, or politicos? Are the new parliamentarians composed predominantly of latter-day party cadres who cashed in their political capital, or the new bourgeoisie who bought electability with their social capital and economic wealth? Outside the regime, what kind of civil society has become incarnate, which preCommunist social structures reborn, what social groups have the transitional structures demobilized, and which ones are being empowered, to play out what repertoires of collective action?

Please use APSA forms and provide full information for panel proposals, and include brief abstracts for individual papers and unifying theme for the panel. I weicome offers to serve as chairs and discussants, and ideas for innovative sessions. 


\section{Division 25. Comparative Politics of \\ Advanced Industrial Societies. \\ Bo Rothstein, University of Göteborg.}

Institutional analysis of present advanced industrialized and democratic states, countries with similar economic and political structures, presents us with an important theoretical challenge: Why is there such a great variation in their political institutions? Below, I have listed ten of the most basic components of the political system and made very crude distinctions between existing opposite institutional forms (ignoring all the possible variation between these two forms):
Party-system:

Electoral system:

Legislative assembly:

Government structure:

Central authority:

Court system:

Local government:

Civil service:

Welfare system:

State-economy relation:
Two-party vs. multiparty system Proportional vs. majoritarian

Unicameral vs. bicameral

Unitarian vs. federalist

Parliamentarism vs. presidentialism Judicial review vs. judicial preview

Weak vs. strong autonomy

Spoils recruitment vs. meritrecruitment

Universal vs. selective

Liberal vs. corporatist
As is readily seen, we get 2 to the 10th, or 1024, possible ways of constructing the major political institutions of an advanced industrial democracy. Not all of these exist, and some combinations appear more than once in the approximately 30 cases (a generous approximation) of such democracies.

I invite proposals for panels, papers and roundtables that could help us answer three questions that follow from this puzzle. The first two are empirical: (a) What explains the enormous variation in institutional arrangements? and (b) What difference do different institutions make for political behavior, political power and the outcome of the political process? The third question is normative: Which institutions are best suited for creating "good" government and societal relations in these societies? All types of institutional analysis (historical, economical, organizational, normative) are welcome, as well as analysis that will try to combine or confront various approaches.

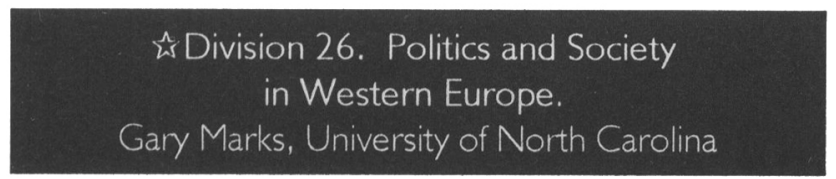

This division is open to paper and panel proposals on any aspect of research on Western Europe. Selection will be based primarily on the potential contribution of proposals to our theoretical and empirical understanding of Western European politics.
Particularly welcome are proposals that build on insights gained in other fields of political science and in other disciplines; proposals that systematically compare institutions, processes, and/or political behavior across western European societies; and proposals that engage the theme of institutions and institutional creation, both within individual countries and at the European level.

Also welcome are proposals on substantive topics that have been subject to intense rethinking in recent years, including the changing competencies of the national state; the reorganization of European political economies; contention over the allocation of authority across different levels of government; and changing patterns of political identity. How have formal and informal norms (i.e. institutions) constrained political actors in these areas, and how have such norms been intentionally - or unintentionally transformed?

Please include a brief abstract detailing the proposed paper. Proposals for panels should include a one page abstract explaining its rationale and an abstract of each paper. There is also some, more limited, scope for other formats, including roundtable, workshop, and "meet the author" sessions. Requests to serve as convenor, discussant or moderator are also invited. In all cases, please include the name, title, address, fax, and email for each participant.

\section{Division 27. International Collaboration.} Lisa Martin, Harvard University

Studies of cooperation among states confront the central issues of international politics: how do states overcome conflicts of interest to achieve mutual benefits; when do attempts to cooperate fail; and how are the benefits of cooperation distributed among states and domestic actors? At the end of the twentieth century, processes of international collaboration appear to have become highly institutionalized. Even the United Nations, despite vast disagreements among its membership and a debilitating financial crisis, exerts pressures toward forms of cooperation not seen during the Cold War.

The institutionalist theme of this year's annual meeting coincides with energetic debates about the role of domestic and international institutions, formal and informal, in international cooperation. The international collaboration division invites proposals for individual papers, for panels, and for roundtables that explore aspects of these debates as well as the subject of international collaboration more generally.

Thinking about "new institutions for a new century" raises intriguing questions for the study of cooperation in the 
traditional fields of international political economy and international security, as well as in emerging issues such as environmental politics and human rights. One set of issues involves the origins of institutions, both domestic and international. How have the demands of international cooperation been reflected in the creation of institutions? Is there in fact a movement toward increasing institutionalization of international politics; if so, why?

A second set of issues, one that has received more scholarly attention but that remains far from settled, involves the effects of institutions. On the international level, what kinds of cooperation are facilitated by what kinds of institutions? How do institutions determine the distribution of benefits from cooperation? Are institutions virtuous constraints, or do they sometimes exacerbate conflict?

The effects of domestic institutions on international cooperation should also engage our attention. For example, as more states move toward democratic forms of government, what effect will this trend have on international politics? Will democracy enhance or complicate the efforts of states to overcome international conflicts of interest? How does the process of transition to democracy influence states' international behavior?

Yet another body of issues involves the effects of institutions other than states or intergovernmental institutions on international cooperation. Topics that might fall under this category include the effects of nongovernmental organizations and of private actors, such as multinational corporations.

\section{Division 28. International Security}

Emerson M.S. Niou, Duke University

Recent world events have been interpreted as signaling a transformation of the international system from one in which international stability is ensured by a balance of power to one in which it is ensured by some type of cooperative arrangement among states, such as an alliance. In fact, the issues raised here are quite similar to those raised in studying the viability of federalism. Just as we ask whether a set of "sovereign" states can cooperate to form a new national state without exogenous enforcement, we can also ask whether a set of national states can cooperate in an anarchic system.

Definitions of alliance in the field of international relations often only describe objectives. As such, they fail to differentiate among alliances by the degree of cooperation each achieves. Alliances can take many different forms and involve various degrees of commitment. The United
Nations, the Soviet bloc, and the North Atlantic Treaty Organization can all be called alliances. The study of alliances as forms of cooperative arrangements between states entails several interesting questions. For example, does a high degree of cooperation within an alliance contribute to stability or instability of an international system? How do we measure the degree of cooperation among allies empirically? is the degree of cooperation a reflection of countries' preferences or their ability to commit credibly? If it is a reflection of preferences, then we need to study the conditions under which countries will choose one form of alliance over another. If it is a reflection of their ability to make credible commitments, then we need to study the design of institutions that will enable countries to credibly commit to a certain degree of cooperation. During the Chinese Warring States period (451-221 BC), for example, one method used by some countries to demonstrate commitment was to exchange prime ministers with each other. The idea was to make sure that one country's foreign policy was transparent to the other.

Proposals for panels, papers and roundtables that offer new insights to the study of alliances as cooperative arrangements are particularly welcome. Proposals on other interesting topics will, of course, be considered. Panel proposals should provide an abstract for the individual papers as well as a statement of the themes that unify the panel as a whole. All paper and panel proposals should be accompanied by a curriculum vita.

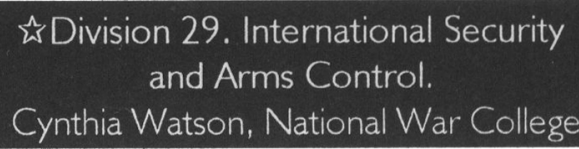

As the twenty-first century dawns, the international community is left with a plethora of institutions seeking to promote international security and arms control. Striking, however, are the quite different philosophies existing around the world regarding the need and efficacy of these organizations for the purposes that each institution seeks to accomplish. Additionally, the evolution of thought on the nature of security leads to the questions regarding the potential usefulness for various institutions that have not traditionally been considered the realm of the security strategist such as those relating to information systems.

Institutions have been a significant instrument in addressing security concerns, particularly during the twentieth century. The United Nations is, however, only the most prominent one of a myriad of attempts to regularize the relations through a body, a charter, and a philosophy that applied national methods to the world at large. In the aftermath of the Gulf War in the 1990s, many scholars and some 
policymakers believed that the "Age of Institutions" and multilateralism was at hand. Has the decade born this out? For the new century, will institutions be the solution to global and local security tensions?

This Division will consider proposals on a broad range of topics relating to arms control and international security. In particular, the division encourages proposals focusing on the annual meeting's theme of concept of new institutions for the new century. In an era when scholars and policymakers are finally coming to grips with the complexity of the security environment around the world, papers relating to institutions which seek to quell economic, social, and political upheavals around the world are desired. Particularly welcomed will be proposals for papers and panels which offer a non-US perspective on institutions concerned with international security and arms control.

\section{Division 30. International Political Economy}

Beth Simmons, Duke University

The study of international political economy is at the intersection of the major concerns of international and comparative politics at the end of the twentieth century. The tremendous growth in international transactions in goods, capital, and increasingly in labor markets has brought "international economic politics" into everyday domestic policy decisions and into broader struggles over domestic and international governance.

This year's theme of "new institutions in a new century" touches on a number of debates that have been central to the study of international political economy. First, it prompts a critical reassessment of our theories (positive and normative) of international economic institutions. Are these institutions efficient, effective, and fair in a rapidly changing global economy? What are the pressures for change, and how has change been accommodated, or resisted, in international institutions for trade, monetary, financial or labor issues?

Secondly, this year's theme prompts us to think about domestic institutions in the face of growing international market pressures. How have labor movements, political parties, regulatory structures, social policy institutions, and indeed basic structures of governance within nations resisted or adapted to increasing exposure to the world economy? To what extent have international economic forces contributed to domestic institutional convergence? Domestic political relations and the institutional structures within which they operate are increasingly influenced by developments in the international economy, though the mechanisms through which such influence is felt remain to be explored.
Finally, we invite research that would connect these issues with broader concerns of international politics. How have international economic relations affected other aspects of international conflict and cooperation? How has the democratic transformation in many states interacted with increasing globalization of market forces? What are the distributive consequences, internationally, within nations and across regions? How have international institutions that have been in existence now for nearly half a decade fostered (or impeded) development?

Papers from all theoretical orientations and methodological traditions are welcome. Every effort will be made to accommodate high quality single-paper submissions.

\section{Division 31. Foreign Policy Analysis. See Division 44.}

$\star$ Division 32. Representative and Electoral Systems Mark E. Rush, Washington \& Lee University

Panels for this section will once again cover the broad range of issues relating to representation and electoral systems in both the United States and other countries. In keeping with the overall theme of the 1997 meeting, "New Institutions for a New Century," papers relating the impact of various electoral institutions to the outcomes of the political process are of particular interest. Similarly, proposals that discuss the impact of constitutional restraints on the effect of electoral systems are encouraged.

While it is likely that one panel will be devoted to recent decisions by the American Supreme Court concerning redistricting, the Voting Rights Act and political parties, proposals addressing the jurisprudence of other nations on the topic are welcome. As always, papers that address recent developments concerning alternative electoral systems, representation theory, and the impact of electoral systems in other countries are encouraged. Insofar as electoral arrangements have direct impacts on the electoral success of specific minority groups, paper proposals which address group-specific concerns are also invited.

This listing is not meant to be exhaustive, and proposals concerning any and all aspects of the field are welcome. The section on Representation and Electoral Systems encourages proposals from the broad range of empirical and normative methodological perspectives and we welcome proposals for individual papers, full panels and roundtables. Requests to serve as discussants or panel chairs are welcome as well. 
$\aleph_{*}$ Division 33. Conflict Processes.

David R. Davis, Emory University

It has been five years since President George Bush argued that international politics would be governed by a "new world order" centered around international institutions. In Bush's vision, these institutions and the norms that evolve with them would facilitate cooperation and limit conflict in the post cold war world. In line with the general theme of the 1997 American Political Science Association Annual Meeting - New Institutions for a New Century - the conflict processes section encourages proposals for papers, panels, posters and round tables that examine the emergence, evolution and influence of international and domestic institutions on international and domestic conflict. In addition, the conflict processes section invites papers that focus on issues related to democratization, the linkages among domestic and international political processes, and the changing incentives and constraints faced by state leaders in the evolving international system.

The conflict processes section encourages proposals that contribute to the cumulation of knowledge within the discipline. Rigorous theoretical and empirical research from any methodological orientation is welcome. We especially encourage proposals that present creative and innovative approaches to the study of conflict processes. Proposals for complete panels, and suggestions for round tables are invited. Requests to serve as discussants or panel chairs should be accompanied by a brief statement of interests and experience. All proposals must include institutional affiliation and address, phone and fax numbers, and email address.

is Division 34. Religion and Politics.

Chris Gilbert, Gustavus Adolphus College

The 1997 program theme "New Institutions for a New Century" fits squarely within the subject matter of scholars of religion and politics. Our subfield of the discipline is ideally suited to exploration of the linkages among institutions, governments and polities. Religion takes on institutional as well as individual forms, and I encourage papers and panel proposals that take on this diversity of forms and focus on future trends. Some possible panel topics include the following:

1) How can the religious markets thesis advanced by Finke and Stark, lannacone, and others, be reconciled with existing political science theories about the rise and decline of civic and political institutions? To what useful ends can the market-based paradigm be applied, either to US politics or cross-nationally?
2) Considerable scholarship has emerged in recent years on the Christian Right and its strategies and influence in US politics. What are the emerging linkages between the movement and the US party system, and what evidence helps us sort out the future of the Christian right as a political and social movement? Of particular interest would be papers that examine the Christian Right from a comparative perspective. Also, papers that focus on the emerging movements of the Christian center and left in US politics would lend valuable perspective to our understanding of this topic.

3) Papers dealing with the multifaceted relationship between church and state might consider the institutional constraints placed on organized religion and how this affects the involvement of religious institutions in civil society. How have churches in Eastern Europe and the former Soviet Union responded to an altered set of institutional constraints, and what difference has this made on politics? As more political analysts and journalists claim conservative parties and views are beginning to predominate across the globe, what roles are churches playing in this process, and what can we anticipate looking to the future?

As with previous years, the division panels will likely reflect the multiple interests of section members, and papers dealing with political theory, public policy, methodological approaches, and political behavior are encouraged. I welcome suggestions for roundtables and whole panels, and these should be forwarded well before the proposal deadline. I also urge consideration of our meeting location -- what resources, individuals, and ideas related to the program and division themes are facilitated by meeting in the nation's capital? People with novel ideas to that end are encouraged to contact me by October 15 .

\section{th Division 35. Science, Technology, and Environmental Politics \\ Priscilla M. Regan, George Mason University}

The theme of the 1997 annual meeting, "New Institutions for a New Century," provides a natural focus for the Science, Technology, and Environmental Politics (STEP) Division. Long-standing research interests in STEP related to this year's theme include: the interdependencies among scientific, commercial, and political institutions; the role and effectiveness of institutions in promoting research and development; institutional arrangements, especially crossing state-federal or national boundaries, for policy implementation and evaluation; and institutional mechanisms for citizen participation and representation.

The STEP Division welcomes proposals that explore all 
aspects of STEP issues, but is especially interested in those that address institutional questions. In many areas of science and technology, including environmental and telecommunications policy, the need for new institutional arrangements to deal with complex policy problems has been recognized and innovative structures and processes have been suggested and attempted. A current and important example concerns the governance issues related to the Global Information Infrastructure (GII). In keeping with this year's theme, proposals that address the following are strongly encouraged: 1) positive and negative constraints that result from institutional arrangements; 2) institutions and social learning; and 3 ) institutional solutions for conflict resolution.

Paper, panel, roundtable, and other session proposals, such as "meet the author" and "scholar-practitioner" panels, are invited. Requests to serve as panel chair or discussant are welcome. The STEP Section also sponsors a research workshop on the Wednesday prior to the start of the APSA meeting. Please contact the Organized Section Chair for details concerning this year's workshop.

Proposals should be in writing and include a one page abstract that covers the significance of the subject, theoretical approach, research perspectives, and methods. With each proposal, please provide full name, title, institutional affiliation, telephone and fax numbers, and email address.

$\hat{\hbar}$ Division 36. Computers and Multimedia.
William J. Ball, Trenton State College

The Computers and Multimedia division is soliciting paper, panel, and workshop proposals which disseminate research on the use of these technologies in both research and teaching. Three examples illustrate how the conference theme of "new institutions for a new century" might be incorporated into the division's panels. The explosive growth of the internet is bound to change the nature of institutions, both public and private--which invites empirical research and theoretical work on the information revolution as it affects the interests of our discipline. Also appropriate would be scholarship on how computer technology, is transforming the "institution" of political science itself--such as the development of new research data archives. Finally, presenters could address the new institutional arrangements required to support the continued deployment of computing and multimedia technology in research and teaching.

A host of other topic areas are suitable for presentation. These include, but are not limited to: new classroom techniques; research on the teaching effectiveness of computer and multimedia applications; creative development of applications for research purposes; evaluations of statistical, multimedia or other research and teaching software; and articulation of the technological skill base now required of the successful political scientist.

Presentations should exhibit high standards of scholarship based on original research, theoretical insight, or practical experience with original applications of technology. Potential presenters should submit the official APSA form plus a detailed abstract (minimum of one full page), and a list of any presentation equipment requested.

Those volunteering to chair a panel or to serve as a discussant should submit evidence of their qualifications to do so.

\section{« Division 37. Political Communication} Michael D. Hagen, Harvard University

The theme of this year's meeting provides a useful vantage point from which to view the study of communication in political science. Among the areas for papers and panels in keeping with the program theme are the following:

1) Institutions figure prominently in our explanations for the shortcomings of many sources of information about politics—of television news, for example, and of campaign rhetoric. Much of what might go under the heading of recommendations for improving political communication, however, takes the form of exhorting individuals to behave more responsibly, journalists and politicians chief among them. There seems to be relatively little empirical research (although there are important exceptions, of course) aimed at distinguishing institutions that enhance the quality of political communication from institutions that diminish it. The statement of this year's theme can serve as a valuable catalyst for comparing communication across institutions.

2) Learning hinges on communication. Students of political communication have long explored the constraints on social learning imposed by the failings of sources, media, and receivers. In principle, at least, the much-heralded advent of the "information superhighway" might help to overcome some of those failings, by providing everyone (at least, everyone who has access) with a direct line to countless sources. Unlimited information poses its own problems, however. What kinds of institutions would make it possible for individuals to distinguish relevant information from the irrelevant, reliable information from the unreliable, new information from old news, in a timely fashion? How would those institutions differ from the institutions that function now to gather, filter, and transmit information? The payoff from theorizing and 
experimentation in this domain would seem to reach well beyond calculating the impact of the Internet. Identifying the features of ideal institutions for political communication can help us understand the effects of the institutions now in place.

3) Communication is part of the solution to any political conflict. There would seem to be a good deal of room for research beyond that truism, on the role of institutions in facilitating the right kinds of communication. What part do the institutions of communication play in fomenting conflict? How do political institutions influence the transmission, tenor, and volatility of political rhetoric? What might be the effects on political communication of alternative institutional arrangements aimed at fostering the peaceful resolution of conflict?

The division invites proposals for papers, panels, and roundtables addressing all aspects of political communication, but especially those related to the structure and operation of political institutions. Proposals from any disciplinary, normative, and methodological perspective are welcome, as are proposals for innovative formats. Proposals should include a brief summary as well as a c.v. for each participant. Offers to serve as a panel chair or discussant also will be gratefully accepted.

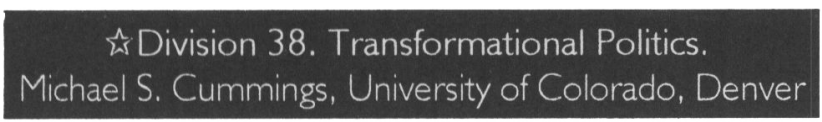

The world is being transformed in subtle and dramatic ways that affect our communities, identities, and daily lives. Indeed, as our millennium draws to a close, the changes we are experiencing are so profound that we may well wonder: "What is a community, a nation, a people? Even closer to home, what is a marriage, a family, a parent? What is a citizen, an American, a person? Has the weakening of traditional institutions left us freer, or merely adrift? What political role shall we play in the dynamic social and physical ecology on which we depend?

As institutions lose their power to capture our loyalties and imaginations, what is left for us as public beings? The answer must be "new institutions for a new century," but what will these be? How will they involve us or alienate us, educate us or confuse us? Transformative processes are redefining where our private and public selves, our local and global selves, our parochial and universal selves, pick up and leave off. Old dichotomies--of men and women, black and white, conservative and liberal, capitalist and socialist--now seem more to obscure than inform our understanding.
The Division on Transformational Politics invites your critical and creative explorations of these and related issues for our 1997 program. We continue to welcome papers, panels, roundtables and poster presentations on the vital issues of gender, race, class, environment, transformational theory, and political activism. We also encourage proposals in such often overlooked areas as ageism, family empowerment, practical utopianism, markets as transformers, transformational authority, "good" and "bad" transformations, problems of "interest-group transformationalism," post-communist transformations, and esthetic or spiritual dimensions of the transformative experience. As most of these topics cut across subdisciplinary boundaries, we hope to continue cosponsoring one or more panels with other Organized Sections.

As always, we try to complement our humanely rigorous formal sessions ("Be sharp, but be nice!") with our informal "Come and Stay Alive" evening sessions and our Sunday social outings to one or more outstanding local attractions. Recent excursions have included canoeing near the Potomac, an afternoon in Central Park, an architectural tour of Chicago, and visits this year to Muir Beach and Muir Woods near San Francisco. We will also continue our tradition of honoring selected members of the Section for excellence in teaching, in research and writing, and in blending scholarship with activism.

Please contact us soon with your proposals, suggestions, questions, or good wishes!

\section{ఓtDivision 39. New Political Science Carl Boggs, National University}

The decline of the public sphere in the US and many other parts of the world focuses our attention on a wide range of problems and issues related to the legacy of diverse political institutions in the twentieth century. The 1997 organizing theme "New Institutions for a New Century" thus offers participants in the New Political Science sessions a great opportunity to critically scrutinize both the development of modern political institutions and their relationship to processes of social change.

One possibility is for us to explore the origins and evolution of various types of states, regimes, and party systems in specific national and/or global contexts. What is the relationship of particular structures, or constellations of structures, to broad-based struggles for change? What institutions tend to be most compatible with the historic goals of social equality, community, and democratic participation? In what ways do specific institutions enhance (or block) the flow of information, decision-making, and 
popular involvement?

Another possibility is to analyze the relationship between distinctly political structures (states, parties, legislatures, etc.) and other types of institutions - economic, military, and social. What is the impact of extra-political structures and forces upon the political sphere, and vice-versa? To what extent do such distinctions even make sense today, end for the future, in a world where institutions are more and more interdependent? What is the influence of global structures such as multinational corporations, the World Bank, the IMF, GATT, and the United Nations on the domestic politics of particular countries?

Yet another possibility is to assess the historical record of political and quasipolitical forms that, to varying degrees, have evolved outside of or even against the state system: local assemblies, trade unions, workers' councils and committees, cooperatives, grassroots movements, and some types of parties. To what extent have these forms been able to generate, and sustain, deep social change and democratic participation? What political strategies linked to specific institutions and practices have been most viable, and which ones seem to promise the best results for the future?

These and related sets of questions, motivated by a critical, probing, irreverent approach to conventional modes of analysis, open up exciting avenues of inquiry that may encourage us to revisit the great traditions of political theory, from the Greeks to Rousseau, Marx, and the anarchists, while also drawing upon more contemporary thought grounded in neo-Marxism, Critical Theory, feminism, ecology, and postmodernism.

We welcome proposals that address the above themes, but papers need not be restricted to this agenda. We particularly encourage contributions from junior colleagues and others who are submitting proposals to New Political Science for the first time.

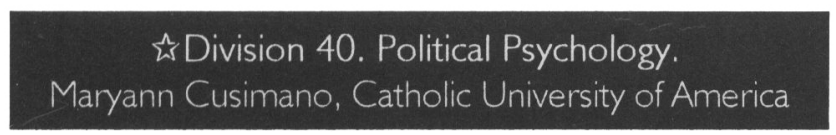

The meeting's theme of New Institutions for a New Century raises a number of questions for the study of political psychology, such as:

1) The relationship between institutions and social learning--how do cognitive limitations and institutional arrangements interact? To what extent do institutions provide information, overcome cognitive limitations, and provide feedback that enables us to learn from our experiences? What psychological factors are involved in institutional dynamics and change?

2) Institutions and conflict--a rising number of internal conflicts are taking place in the Post Cold War era. What psychological factors are involved in conflict, and can institutional arrangements work to mitigate or resolve nationalist, ethnic, racial, or other types of conflict? In addition to proposals related to the conference's overall theme, this division is also interested in other current topics in political psychology, particularly work that explores the intersection of different theoretical approaches or the links between individual and aggregate behavior.

These questions clearly overlap with issues in foreign policy, comparative politics, international security, political behavior, political communication, and other areas. The division is particularly interested in cosponsorship with other divisions. Proposals must indicate if they are also being submitted to other divisions. Be sure to include the complete name, professional affiliation, and complete address information (mail, telephone, FAX, and email) for each and every author of the paper.

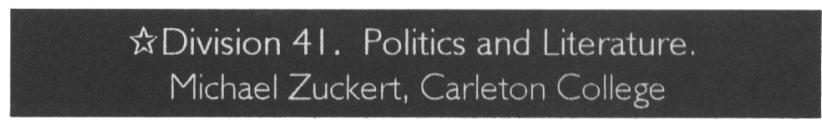

The 1997 theme, "New Institutions for a New Century" is an especially apt one for the Politics and Literature section, for some of the best literary art involving politics has centered on political institutions. In line with the 1997 theme, the section is especially interested in papers and panels on the three following themes. (In what follows, "literature" should be understood in the broadest sense to include modes of expression such as drama, film, and poetry):

1. Literature and Political Institutions. What does literature add to our understanding of political institutions? Does the particularly "inside view" that literature often affords contribute insights that non-literary modes of study cannot match? What picture do we get of political institutions from literary works that attempt to present them? Is literature necessarily a distorting medium for the presentation of political institutions?

2. Literature and the Institutions of the Future: One of the great functions of literature, as a sphere infused with imagination, is the projection of futures, either utopian or dystopian, or some mix of the two. What do the various genres of literature that are particularly concerned with the future - e.g., science fiction and fantasy - tell us about the future? About literary sensibilities regarding the future? About the historical or political setting in which the literary projections were conceived? 
3. Literature and Politics: an Institutional Approach. The section is especially interested in encouraging papers on the broad topic of the politics of literature and literary institutions. What are the mechanisms by which some literature is authenticated, highlighted, given éclat, and others not? What are the politics of e.g. the Nobel Prize Awards for literature? What politics do winners of Nobel Prizes engage in via their acceptance speeches? What are the politics of "canon formation"? What of the politics of debates about censorship or use of literature in the schools?

«mDivision 42. Undergraduate Education.

Donna Schlagheck, Wright State University

The classroom setting and the lecture format are among the oldest institutions we rely upon to teach undergraduates the science of politics. The strengths and constraints of these institutions will be the focus of this division, with particular attention directed at the new formats for teaching and learning created by technology and the trend toward more "active" learning. In addition to considering new formats and institutions for undergraduate education, this division also will provide new formats for the presentation of ideas and opportunities for dialogue and debate. Traditional panel proposals, workshops, round tables, and multimedia presentations and other formats will comprise the types of proposals sought by this division.

Before we address the question of undergraduate education, we must consider the training and preparation we provide to graduate students who soon will find themselves responsible for teaching undergraduate courses. The "apprenticeship" or "learning by observing, followed by trial-and-error in the classroom" method is often criticized. Proposals for panels or workshops devoted to new approaches to the training of teachers of political science are strongly encouraged, with the subjects of classroom climate and compliance with federal regulations concerning Americans With Disabilities (both physical and learning disability) being of particular interest. Directors of graduate studies especially are urged to participate in this section.

Experiential education as a component of and complement to the classroom experience is a field of growing interest to new and experienced undergraduate educators. Proposals for panels or roundtables that focus on managing internships, study abroad, and simulations such as Mock Trial or Model United Nations programs are suggested. Of special interest is the appearance of new "service learning" and "servant leadership" programs that are emerging across undergraduate curricula, often as requirements for graduation. Faculty who are employing distance learning technologies are invited to propose workshops to discuss the opportunities and limitations of this new delivery system. The challenge of assessing the learning outcomes of these new teaching and learning formats is an important and persistent question; paper and panel proposals on this subject are encouraged.

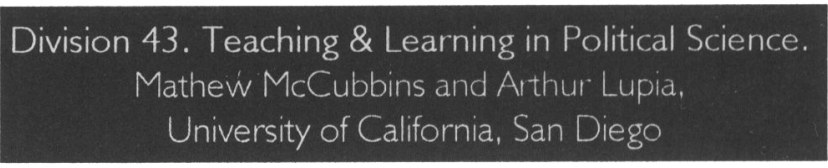

Modern politics confronts people with dilemmas that are unfamiliar to their own experience and uncorrected by trial and error. As a result, personal experience is usually a bad way to acquire political knowledge. However, other sources of political information - such as newspapers, television programs, and the oral or written testimony of others - are often available. Can political actors learn what they need to know?

How people learn affects political behavior and outcomes. Therefore, understanding the dynamics of political learning is an essential part of understanding politics. In 1997, the Learning in Political Science section focuses on research about learning in political contexts. The section will feature three types of panels:Some panels will feature gametheoretic approaches to the study of political learning. We will give priority to papers that focus on the strategic foundations of political communication. We are interested in research that explains how incentives and strategic considerations affect both what people say and what they are willing to believe. Since institutions affect incentives, these panels will also provide an ideal setting to debate one of the conference's three major themes: the relationship between institutions and learning.

Some panels will feature cognitive approaches to the study of political learning. We will give priority to papers that build scientific arguments about what voters, legislators, or jurors can know, learn or do. We are interested in research that explains how the systematic cognitive limitations and adaptive capacities that humans share affect our ability to govern ourselves. We welcome research that builds upon either cognitive science's or psychology's intellectual foundations.

Some panels will feature experiments about political learning. We will give priority to papers that describe critical experiments -- tests that are directly related to a theoretically-generated hypothesis and tests whose outcomes are not obvious. We are interested in empirical research that clarifies the conditions under which people can persuade each other, mislead each other, or provide each other with simple effective information cues. 
There is an emerging population of social scientists who examine political learning. In 1997, the Learning in Political Science section will reinforce this trend by featuring cuttingedge research on learning from a wide range of scientific traditions. Paper proposals should include an abstract that specifies how the research challenges or advances existing debates on leaming in political contexts. We welcome your submissions.

«t Division 44. Domestic Sources of Foreign Policy.

Joseph D. Hagan, University of West Virginia, and

John Cotman, Howard University

This section combines last year's divisions on "foreign policy analysis" and "public opinion and foreign policy" and, as such, encompasses the full variety of domestic sources of foreign policy. We seek papers, panels, and roundtables that present systematic analyses (both qualitative and quantitative) of societal, statist, and/or decision making influences on foreign policy choice, particularly as related to war proneness, cooperation, or restructuring in international affairs. We also encourage discussions that place foreign policy explanations into the larger stream of international relations theory. Topics of this sort could include, for example, the theoretical power of "second image" phenomena relative to systemic constraints, the extent to which states act as agents shaping world politics, and the place of such arguments in neorealist, neoliberal, and radical perspectives.

This year, there are also two areas of special interest for which we would like to have several panels, and/or roundtables. The first reflects this year's conference theme-the role of institutions. The theme is especially appropriate for this division, because much current research suggests that institutions condition the impact of domestic politics and interests on foreign policy. Examples of these insights include (1) how institutions preclude "hijacking" of the national interest by narrow parochial interests, (2) how the democratic peace can be "unpacked" by exploring the variety of institutional relationships in both democratic and authoritarian regimes, (3) how new, non-institutionalized democracies may prove to be more--not less--bellicose than their authoritarian predecessors, and (4) how institutions condition leaders' responses to public opinion and societal interests.

The second special interest is to have greater focus on the analysis of non-Western, especially Third World, foreign policy. Much recent, mainstream foreign policy research, in responding to systemic theories as well as post-cold war changes, has tended toward a "great power" bias. We seek several panels or roundtables that address not only the distinctive sources of Third World foreign policies, but also such topics as the zones of peace in certain regions, economic dependence and foreign policy compliance, and the altered systemic context of Third World foreign policies after cold war bipolarity.

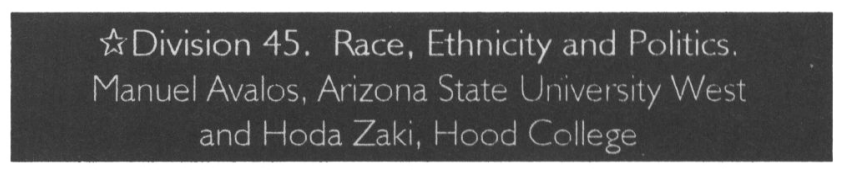

The APSA's newest section focuses primarily, but not exclusively on the politics of Native, African, Latino and Asian American communities in the United States, and in other countries of the Western Hemisphere. Since the arrival of Columbus, what has been defined as the "race problem" in the Western Hemisphere (and the Americas in particular) has generated antagonisms between the enslaved and masters, natives and settlers, new immigrants and older residents, and workers divided by wage discrimination, culture and gender. At the same time, however, extensive interracial contact and interaction have created a complex and distinctive blend of political cultures. We hope to examine how racial conflict and cooperation, domination and fusion, and cultural hegemony and resistance, have all contributed to the contemporary world of political identities, ideas and institutions. Therefore, in keeping with this year's program theme, "New Institutions for a New Century" we are soliciting papers which seek to examine the ways in which political institutions have historically impeded and/or maintained racial/ethnic and racially-gendered inequalities in politics. Political institutions are defined broadly to include among other things political parties, interest groups, the media, bureaucracies, and state, local, and national governments. We welcome papers which examine institutional resistance to social/racial change, institutional change and democracy, and the development of counter-hegemonic institutions and movements. We are especially interested in papers and panel proposals which incorporate interdisciplinary theoretical frameworks to the study of racial/ethnic and racially gendered political inequalities. Papers and panels with a policy focus are welcome. As we near the end of the 20th century we hope that historical analyses of institutional arrangements and their successes and failures will compel us to consider alternative institutional arrangements which would significantly promote and achieve political equality for all members of racial and ethnic groups presently excluded from contemporary political institutions.

(Note: Divisions with wis are APSA Organized Sections) 